\title{
SPRAWOZDANIE Z IV KONFERENCJI SIECI ZRÓWNOWAŻONEGO ROZWOJU „ZASADA ZRÓWNOWAŻONEGO ROZWOJU W WYMIARZE GOSPODARCZYM I EKONOMICZNYM" - TORUŃ, DNIA 25 LISTOPADA 2014 ROKU
}

\section{REPORT ON THE FOURTH CONFERENCE OF SUSTAINABLE DEVELOPMENT NETWORK "THE PRINCIPLE OF SUSTAINABLE DEVELOPMENT IN BUSINESS AND ECONOMIC ASPECT" - TORUŃ, $25^{\text {TH }}$ NOVEMBER, 2014}

\section{STRESZCZENIE}

W dniu 25 listopada 2014 roku w Toruniu odbyła się IV Konferencja Sieci Zrównoważonego Rozwoju „Zasada zrównoważonego

" Magister prawa i administracji, doktorantka w Katedrze Prawa Ochrony Środowiska Wydziału Prawa i Administracji Uniwersytetu Mikołaja Kopernika w Toruniu. 
rozwoju w wymiarze gospodarczym i ekonomicznym" zorganizowana przez Katedrę Prawa Ochrony Środowiska oraz Koło Naukowe Prawa Ochrony Środowiska Wydziału Prawa i Administracji UMK w Toruniu. Wydarzenie odbyło się dzięki wsparciu pana Piotra Całbeckiego - Marszałka Województwa Kujawsko-Pomorskiego, Wojewódzkiego Funduszu Ochrony Środowiska i Gospodarki Wodnej w Toruniu oraz pana prof. Tomasza Justyńskiego - Dziekana Wydziału Prawa i Administracji UMK w Toruniu. Główne cele Konferencji dotyczyły: analizy gospodarczych i ekonomicznych aspektów zrównoważonego rozwoju w kontekście ochrony środowiska, identyfikacji gospodarczego prawa środowiska, analizy reguł wyważania sprzecznych interesów oraz prawa ochrony środowiska w praktyce przedsiębiorcy. Toczone $\mathrm{w}$ toku konferencji dyskusje były doskonałym polem wymiany poglądów i doświadczeń pomiędzy przedstawicielami nauki oraz praktykami. Wydarzenie było dowodem na to, że zasada zrównoważonego rozwoju jest niezwykle ważnym i trudnym kierunkiem badań naukowych. Na uwagę zasługuje także bardzo szerokie ujmowanie tej materii, a także powiązania z innymi elementami systemu prawnego.

\section{Słowa kluczowe}

Zasada zrównoważonego rozwoju; konferencja naukowa.

\section{ABSTRACT}

On 25 November 2014, the Fourth Conference on Sustainable Development Network "The principle of sustainable development in business and economic aspect" took place in Torun. The conference was organised by the Department of Environmental Law and Scientific Association of Environmental Law of Faculty of Law and Administration of Nicolaus Copernicus University in Torun. The event was held with the support of Mr. Piotr Całbecki - Marshal of the Kuyavian-Pomeranian Voivodeship, Voivodeship Fund for Environmental Protection and Water Management in Toruń and Mr. professor Tomasz Justyński - Dean of the Faculty of Law and Administration of Nicolaus Copernicus University in Toruń. The main objectives of the Conference included: economic analysis and economic aspects of sustainable development in the context of environmental protection, identification of economic environmental law, the analysis of the rules of balancing 
conflicting interests and environmental law in the practice of entrepreneur. Discussions carried out during the conference were an excellent field of exchange of views and experiences between representatives of science and practice. The event was proof that the principle of sustainable development is a very important and challenging direction for research. It is worth mentioning that this matter is widely recognized and it links with other elements of legal system.

\section{Keywords}

The principle of sustainable development; scientific conference.

W dniu 25 listopada 2014 roku w Toruniu odbyła się IV Konferencja Sieci Zrównoważonego Rozwoju „Zasada zrównoważonego rozwoju w wymiarze gospodarczym i ekonomicznym" zorganizowana przez Katedrę Prawa Ochrony Środowiska oraz Koło Naukowe Prawa Ochrony Środowiska Wydziału Prawa i Administracji UMK w Toruniu. Wydarzenie uzyskało wsparcie pana Piotra Całbeckiego - Marszałka Województwa Kujawsko-Pomorskiego, Wojewódzkiego Funduszu Ochrony Środowiska i Gospodarki Wodnej w Toruniu oraz pana prof. Tomasza Justyńskiego - Dziekana Wydziału Prawa i Administracji UMK w Toruniu. Konferencja odbyła się w ramach Polskiej Sieci Naukowej „Badania naukowe i prace rozwojowe na rzecz realizacji zrównoważonego rozwoju", w ramach której współpracuje Katolicki Uniwersytet Lubelski Jana Pawła II, Uniwersytet w Białymstoku oraz Uniwersytet Mikołaja Kopernika w Toruniu.

Patronat honorowy nad wydarzeniem objął pan Piotr Całbecki - Marszałek Województwa Kujawsko-Pomorskiego, pani Emilia Kawka-Patek - Prezes Zarządu Wojewódzkiego Funduszu Ochrony Środowiska i Gospodarki Wodnej w Toruniu oraz pan prof. Tomasz Justyński - Dziekan Wydziału Prawa i Administracji UMK w Toruniu.

W składzie Komitetu Organizacyjnego Konferencji znaleźli się: jako Przewodniczący - pan prof. dr hab. Bartosz Rakoczy (Kierownik Katedry Prawa Ochrony Środowiska WPiA UMK w Toruniu), jako Sekretarz - mgr Martyna Walas (doktorantka w KPOŚ WPiA UMK), dr Karolina Karpus (adiunkt w KPOŚ WPiA UMK), dr Małgorzata Szalewska (adiunkt w KPOŚ WPiA 
UMK), mgr Jacek Pakuła (Pełnomocnik Dziekana WPiA ds. Kontaktów z Interesariuszami), a także przedstawiciele Koła Naukowego Prawa Ochrony Środowiska: stud. Anna Kotańska, stud. Katarzyna Mojsiewicz, stud. Bartłomiej Gmaj oraz stud. Łukasz Kwiatkowski.

Zamiarem Organizatorów było poddanie szczegółowej analizie zasady zrównoważonego rozwoju przede wszystkim w jej wymiarze gospodarczym i ekonomicznym. Zasada ta jest jedną z ważniejszych, jeśli nie najważniejszą, zasadą współczesnego prawa ochrony środowiska. Celem Konferencji była przede wszystkim wymiana poglądów, a także przedstawienie wyników badań naukowych skoncentrowanych wokół tytułowej materii, a zwłaszcza wokół problemów pojawiających się przy zetknięciu ochrony środowiska z gospodarką.

Konferencja została uroczyście otwarta przez pana prof. Tomasza Justyńskiego - Dziekana Wydziału Prawa i Administracji UMK w Toruniu oraz pana prof. dr. hab. Bartosza Rakoczego. Główne zagadnienia tematyczne Konferencji dotyczyły: analizy gospodarczych i ekonomicznych aspektów zrównoważonego rozwoju w kontekście ochrony środowiska, identyfikacji gospodarczego prawa środowiska, analizy reguł wyważania sprzecznych interesów oraz prawa ochrony środowiska w praktyce przedsiębiorcy. Debata została podzielona na trzy panele. Panel pierwszy poprowadzony został przez pana dr. hab. Zbigniewa Bukowskiego, prof. UKW, panel drugi - przez panią dr Annę Haładyj, zaś panel trzeci - przez pana prof. dr. hab. Bartosza Rakoczego. W trakcie całej konferencji zostały przedstawione następujące wystąpienia:

- Zasada zrównoważonego rozwoju jako wyznacznik stanowienia ograniczeń na obszarach chronionych - mgr Michał Borowiak (Generalna Dyrekcja Ochrony Środowiska);

- Własność urzadzeń wodnych - dr hab. Jerzy Rotko, prof. INP PAN (Polska Akademia Nauk);

- Ekonomiczne aspekty zaniechania działań naprawczych $w$ ustawie o zapobieganiu szkodom $w$ środowisku $i$ ich naprawie - prof. dr hab. Bartosz Rakoczy (Uniwersytet Mikołaja Kopernika w Toruniu); 
- Prawne fundamenty zrównoważonej gospodarki leśnej i ochrony lasów. Fakty i postulaty - dr hab. Adam Habuda, prof. INP PAN (Polska Akademia Nauk);

- Kolizja interesów $w$ procesie wyłaczania gruntów z produkcji rolnej i leśnej - dr Małgorzata Szalewska (Uniwersytet Mikołaja Kopernika w Toruniu);

- Działalność mikroprzedsiębiorcy a ochrona środowiska dr hab. Zbigniew Bukowski, prof. UKW (Uniwersytet Kazimierza Wielkiegow Bydgoszczy);

- Międzynarodowe gospodarcze prawo środowiska jako instrument realizacji zasady zrównoważonego rozwoju dr Maciej Nyka (Uniwersytet Gdański);

- Ubezpieczenia ekologiczne jako instrument transferu ryzyka przedsiębiorcy $w$ zakresie szkody ekologicznej - mgr Michał Marszelewski (Uniwersytet Mikołaja Kopernika w Toruniu);

- Charakter prawny raportu o oddziaływaniu przedsięwzięcia na środowisko - mgr Jan Szuma (Wojewódzki Sąd Administracyjny w Poznaniu);

- Determinanty administracyjnej kary pieniężnej $w$ świetle ustawy Prawo ochrony środowiska - dr Karolina Szuma (Europejska Wyższa Szkoła Prawa i Administracji w Warszawie);

- Zrównoważony rozwój i bezpieczeństwo energetyczne dr Leszek Karski (Uniwersytet Kardynała Stefana Wyszyńskiego w Warszawie);

- Transgraniczne przemieszczanie odpadów $w$ świetle zasady zrównoważonego rozwoju - dr Karolina Karpus (Uniwersytet Mikołaja Kopernika w Toruniu);

- Przestrzeganie zasady zrównoważonego rozwoju w procesie planowania przestrzennego na tle orzecznictwa sqdowo administracyjnego - dr Zygmunt Wiśniewski (Politechnika Wrocławska/Wojewódzki Sąd Administracyjny we Wrocławiu);

- Czy istnieje remedium na konflikt interesów $w$ zagospodarowaniu przestrzennym? Uwagi na tle zasady zrównoważonego rozwoju - dr Marta Woźniak (Uniwersytet Opolski); 
- Wykładnia przesłanek „konieczności” oraz „nadrzędności” przy ocenie interesu publicznego o charakterze społecznym lub gospodarczym przeciwstawianego celom ochrony ustanowionym na podstawie przepisów o ochronie przyrody i prawa wodnego - mgr Michał Behnke (Kancelaria Radców Prawnych CIC Danuta Pikor Michał Behnke Sp.p.).

W Konferencji wzięło udział ponad 60 osób. W związku z bardzo szerokim zakresem tematycznym Konferencji dyskusja była wielowątkowa. Uczestnicy we wspomnianych wystąpieniach oraz w licznych debatach podejmowali próby zdefiniowania samego pojęcia zrównoważonego rozwoju. Wskazywano na problem istnienia $\mathrm{w}$ wielu sprawach z zakresu ochrony środowiska różnego rodzaju konfliktów. Jak wskazywano, są to przede wszystkim konflikty między interesem publicznym i prywatnym. Zauważono jednak także, że w związku z rozdrobnieniem organów odpowiedzialnych za wykonywanie zadań z zakresu ochrony środowiska, coraz częściej pojawiają się konflikty w obrębie tylko interesu publicznego. Uczestnicy Konferencji starali się także odpowiedzieć na pytane, jakie miejsce w całym systemie ochrony środowiska zajmuje człowiek. Tak interesujące rozważania, a także problemy Organizatorzy pragną zawrzeć w publikacji pokonferencyjnej obejmującej referaty przygotowane przez uczestników, której wydanie planowane jest na pierwszy kwartał 2015 roku.

Kontakt e-mail:

martyna.walas@gmail.com 